\title{
Effect of haloperidol, suckling, oxytocin and hand milking on plasma relaxin and prolactin concentrations in cyclic and lactating pigs
}

\author{
June Z. Kendall, Gail E. Richards* and Li-chen N. Shih
}

Department of Obstetrics and Gynecology and Department of Pediatrics, University of Texas Health Science Center at Houston, 6431 Fannin, Houston, Texas 77030, U.S.A.

\begin{abstract}
Summary. Prolactin secretion was stimulated in 5 cyclic gilts during the luteal phase (Day 10-13) with $5 \mathrm{mg}$ haloperidol given i.v. Stimulation of prolactin secretion was also attempted by inducing milk let-down by suckling (4 sows), or by the injection of $1 \mathrm{mg}$ oxytocin i.v. followed by hand milking ( 3 sows). Plasma prolactin concentrations increased significantly 1-2 h after haloperidol injection, and in 3 of 4 sows during suckling $(P=0.001)$; plasma relaxin concentrations did not change significantly at these times. No change was observed in plasma prolactin or relaxin concentrations at $15 \mathrm{~min}$ or $1-2 \mathrm{~h}$ after oxytocin injection and hand milking. Plasma relaxin concentrations ranged from below the sensitivity of the assay $(100 \mathrm{pg} / \mathrm{ml})$ to $450 \mathrm{pg} / \mathrm{ml}$ in lactating sows and from 100 to $2000 \mathrm{pg} / \mathrm{ml}$ in cyclic gilts. The results suggest that in cyclic gilts treated in the luteal phase with a dopaminergic receptor blocker, and in lactating sows during suckling, elevations in plasma prolactin concentrations were not accompanied, during the same period, by detectable changes in relaxin concentrations.
\end{abstract}

\section{Introduction}

The mechanisms regulating relaxin secretion from the porcine ovary during pregnancy, lactation or the oestrous cycle are not known. The apparent similarity in the timing of changes in plasma prolactin and relaxin concentrations during the cycle and late pregnancy in the pig (Dusza \& Krzymowska, 1979, 1981; Sherwood \& Rutherford, 1981; Sherwood, Nara, Welk, First \& Rutherford, 1981) and during suckling in the ewe (Bryant \& Chamley, 1976) suggested to us that one mechanism may control the secretion of both hormones. Against this view, however, are results from studies on prolactin and relaxin secretion during late pregnancy; peak plasma concentrations of these hormones are occasionally asynchronous in pigs experiencing normal parturition (Kendall, Richards, Shih \& Farris, 1982) and although a surge in prolactin occurs before farrowing in gilts carrying singletons relaxin concentrations fluctuate between 5 and $10 \mathrm{ng} / \mathrm{ml}$ (Kendall \& Richards, 1983). Conversely, in gilts treated near term with bromocriptine (Taverne et al., 1982) prolactin levels remain low whereas plasma relaxin concentrations follow the pattern observed in untreated gilts and rise before farrowing.

The present study further examines the relationship of relaxin and prolactin secretion in cyclic and lactating sows. Stimulation of prolactin secretion was attempted and plasma relaxin and prolactin concentrations measured.

* Present address: Department of Pediatrics, University of Texas Medical Branch, Galveston, Texas 77550 , U.S.A.

$0022-4251 / 83 / 050271-07 \$ 02 \cdot 00 / 0$

(C) 1983 Journals of Reproduction \& Fertility Ltd 


\section{Materials and Methods}

\section{Animals}

The study was carried out on cross-bred sows which were exhibiting regular oestrous cycles or had experienced normal pregnancy and parturition and were suckling litters of 10 .

Lactating sows. Samples were obtained from 7 sows within 21 days of farrowing. Piglets were removed from the sow $6 \mathrm{~h}$ before sampling. In Exp. 1 blood was obtained from an ear vein of 3 sows before, during and after suckling. Samples were taken at $10 \mathrm{~min}, 5 \mathrm{~min}$ and immediately before the piglets were returned to the dam. The piglets were allowed to suck for $15 \mathrm{~min}$ and samples were then taken at 5, 10, 15, 35 and $180 \mathrm{~min}$ from this time. Each piglet sucked intermittently for $90 \mathrm{~min}$. During this period, therefore, the dam was sucked continuously by one or more piglets. In one sow sampled on Day 3 of lactation, blood was taken from an anterior vena caval catheter at $1-\mathrm{min}$ intervals over a 5-min period before, during and after a 5-min period of suckling. In Exp. 2, 3 sows received $20 \mathrm{i} . \mathrm{u}$. oxytocin i.v. to stimulate milk letdown. The sows were hand milked for $20 \mathrm{~min}$ after the injection. A blood sample was taken from an ear vein $5 \mathrm{~min}$ before, and $15 \mathrm{~min}$ and 1 or $2 \mathrm{~h}$ after oxytocin administration.

Cyclic sows. During the luteal phase of the cycle (Day 10-13), $5 \mathrm{mg}$ haloperidol (McNeil, Fort Washington, PA), a dopaminergic receptor blocking agent, was administered as an i.v. bolus to 5 pigs. Blood samples were collected from the anterior vena cava at $\mathbf{l} \mathbf{h}$ and immediately before injection and at 1 and $2 \mathrm{~h}$ after injection. All samples were collected into heparinized syringes, transferred to glass tubes and centrifuged at $1500 \mathrm{~g}$ for $15 \mathrm{~min}$. The plasma was divided into aliquots and stored at $-20^{\circ} \mathrm{C}$ until assayed.

\section{Radioimmunoassays}

Relaxin, prolactin and progesterone concentrations were measured by radioimmunoassays as previously described (Kendall et al., 1982).

Relaxin. The sensitivity of the relaxin assay was $16 \mathrm{pg}$ (Ekins \& Newman, 1970). However, the $\log$ - $\log$ it transformation showed a linear regression from 50 to $1000 \mathrm{pg}$ with a precise detection limit of $100 \mathrm{pg} / \mathrm{ml}$. The mean slope of the regression line for 6 radioimmunoassays was $-0.82 \pm$ 0.01 (s.e.). Epidermal growth factor, fibroblast growth factor, nerve growth factor, porcine insulin, proinsulin, prolactin, FSH or LH did not react in $\mu$ g amounts in the relaxin assay (Text-fig. 1). When late pregnancy pig serum or NIH porcine relaxin 'spiked' with ${ }^{125}$ I-labelled relaxin was filtered through a column of Sephadex G-50, the immunoreactive relaxin co-eluted with ${ }^{125} \mathrm{I}$ labelled relaxin (Text-fig. 2).

Prolactin. The antiserum was raised in rabbits against ovine prolactin (Aubert, Grumbach \& Kaplan, 1974). Porcine prolactin for iodinated and unlabelled ligand was provided by $\mathrm{Dr} \mathrm{C} . \mathrm{H}$. Li (Hormone Research Laboratory, University of California, San Francisco, California). The sensitivity of the prolactin assay was $200 \mathrm{pg}$ (Ekins \& Newman, 1970). The cross-reactivity of porcine growth hormone in the assay was $1.9 \%$ whilst that of porcine $\mathrm{LH}, \mathrm{FSH}$ and relaxin was less than $0.01 \%$.

The intra-assay coefficient of variation of a plasma sample from a pig during the luteal phase of the cycle assayed in replicate was $4.5 \%$ for relaxin $(332 \mathrm{pg} / \mathrm{ml} \pm 15 \mathrm{s.d}$.; $400 \mu \mathrm{l} \mathrm{sample})$ and $8 \cdot 5 \%$ for prolactin; the inter-assay coefficient of variation for the same sample assayed in 3 assays was $13 \cdot 1 \%$ for relaxin and $12.0 \%$ for prolactin.

Progesterone. The antiserum was generated against 4-pregnan-11 $\alpha$-ol-3,20-dione-11-hemisuccinate-BSA. Various cross-reactivities against related steroids were $20.9 \%$ for 4 -pregnen-11 $\alpha$-ol3,20-dione; $18.0 \%$ for $5 \alpha$-pregnen-3,20-dione; $0 \cdot 09 \%$ for 4 -pregnen- $17 \alpha$-ol-3,20-dione; $0 \cdot 13 \%$ for 4 -

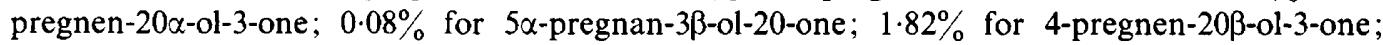
$0.31 \%$ for 5 -pregnen-3 3 -ol-20-one; $1.9 \%$ for 4-pregnen-21-ol-3,20-dione; $0.47 \%$ for 4 -pregnen- 


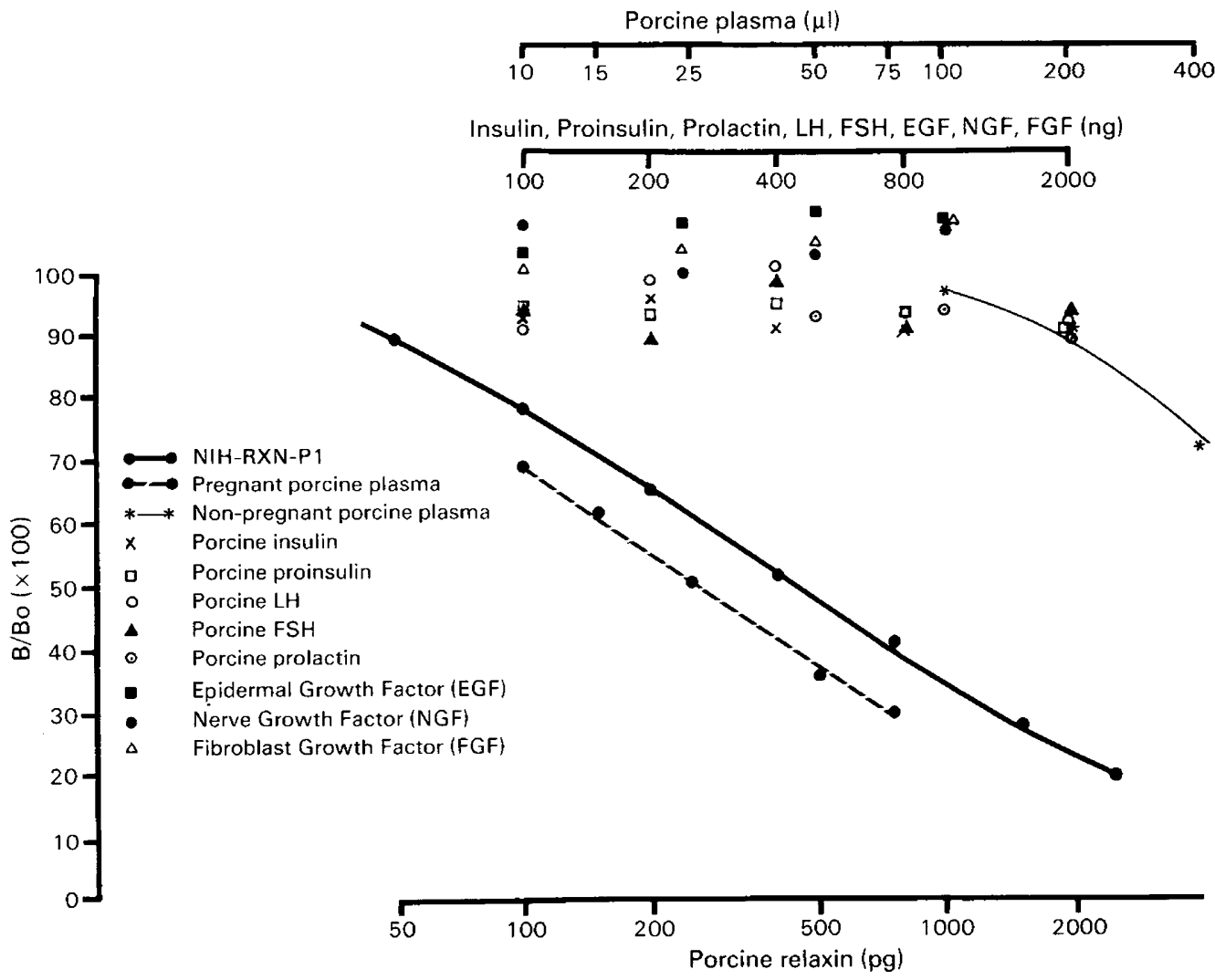

Text-fig. 1. Dose-response curves for NIH porcine relaxin, non-pregnant pig plasma, pregnant pig plasma, porcine insulin, porcine proinsulin, porcine $\mathrm{LH}$, porcine $\mathrm{FSH}$, porcine prolactin, epidermal growth factor, fibroblast growth factor and nerve growth factor.

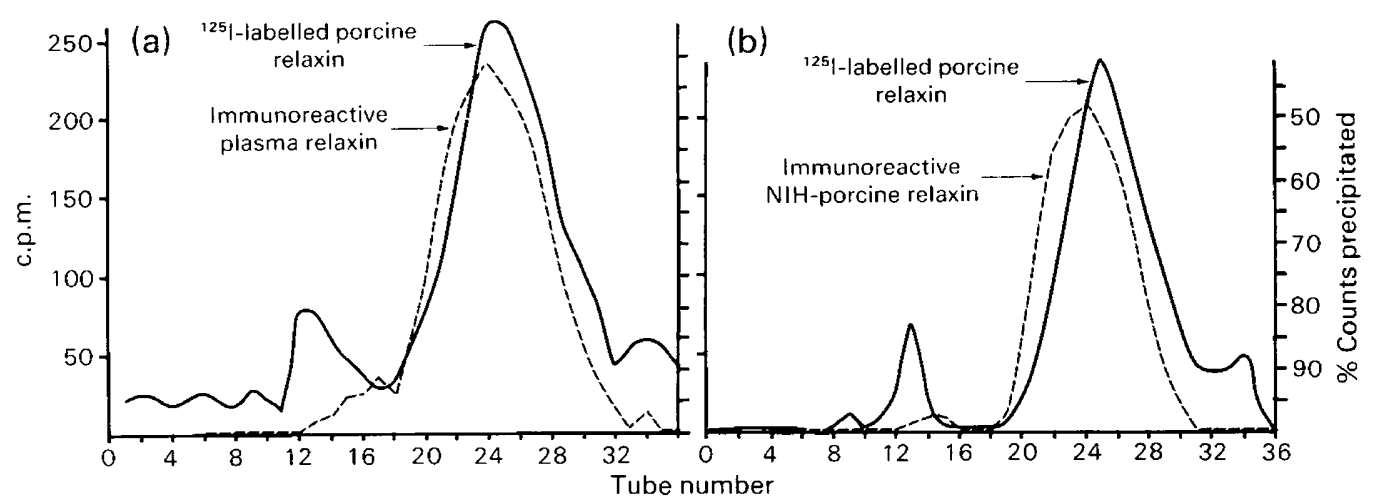

Text-fig. 2. Gel filtration of (a) late pregnancy pig plasma or (b) NIH porcine relaxin in PBS buffer 'spiked' with ${ }^{125}$ I-labelled relaxin. Late pregnancy pig plasma $(500 \mu 1)$ or NIH porcine relaxin standard (100 $\mathrm{ng}$ ) containing approximately $140 \mathrm{pg}^{125} \mathrm{I}$-labelled relaxin was filtered through a $1 \times 30 \mathrm{~cm}$ column of Sephadex G 50, equilibrated with $0.05 \mathrm{M}$-sodium phosphate buffer, $\mathrm{pH} 7 \cdot 5$, containing $0.25 \%$ gelatin $(\mathrm{w} / \mathrm{v})$. The flow rate was $9 \mathrm{ml} / \mathrm{h}$, with $0.6 \mathrm{ml}$ fractions collected at 4 -min intervals in $12 \times 75 \mathrm{~mm}$ glass tubes. The elution profile for ${ }^{125} \mathrm{I}$-labelled relaxin was determined in a Beckman 8000 gamma spectrophotometer. The elution profile for the immunoreactive substance within late pregnancy pig plasma was identified by measuring duplicate $400 \mu \mathrm{l}$ samples from each tube in the relaxin radioimmunoassay. 
$11 \beta, 21$-diol-3,20-dione; $0 \cdot 01 \%$ for 4-pregnen- $11 \beta, 17 \alpha, 21$-triol-3,20-dione; $0.04 \%$ for 4 -androsten$17 \beta$-ol-3-one; and $0.02 \%$ for $5 \alpha$-andronstan-17 $\beta$-ol-3-one. Progesterone was extracted from $500 \mu 1$ plasma with $3 \mathrm{ml}$ petroleum ether (b.p. $42-60^{\circ} \mathrm{C}$; Fisher Scientific). Extraction efficiency was 86.3 $\pm 2.9 \%$. A $400 \mu \mathrm{l}$ sample of plasma was assayed with an assay sensitivity of $75 \mathrm{pg} / \mathrm{ml}$ (Ekins \& Newman, 1970). The inter-assay coefficient of variation was $7.5 \%$ for boar plasma (mean \pm s.d. $1.74 \pm 0.13 \mathrm{ng} / \mathrm{ml}, n=4)$ and for a pool of samples from pregnant pigs $(17.0 \pm 2.69 \mathrm{ng} / \mathrm{ml}, n=4)$.

\section{Statistics}

Hormone measurements were analysed by analysis of variance (Statistics with Daisy, Apple II Applesoft).

\section{Lactating pigs}

\section{Results}

In 3 of 4 pigs mean prolactin concentrations during suckling showed a significant increase over the mean concentrations obtained before $(P=0.05$ for Pig $30, P<0.01$ for Pigs 81 and 101) and after $(P<0.01$ for Pig 30) suckling (Text-fig. 3). Relaxin concentrations were undetectable in the 3 sows sampled infrequently (Nos 23, 81 and 101). Relaxin ranged from 130 to $450 \mathrm{pg} / \mathrm{ml}$ in Pig 30 which was sampled at 1 -min intervals. Although the pattern of relaxin in Pig 30 was not significantly different before and during suckling, the mean concentration after suckling was higher than before $(P=0.05)$ or during $(P<0.01)$ suckling. Oxytocin-stimulated milk ejection was maintained by hand milking over a 15 min period. Plasma concentrations of relaxin were below the sensitivity of the assay. Plasma prolactin concentrations $(\mathrm{ng} / \mathrm{ml})$ were similar before $(-5 \mathrm{~min} ; 5 \cdot 7$, $28 \cdot 1,25 \cdot 6)$ and at the end of $(+15 \mathrm{~min} ; 6 \cdot 8,22 \cdot 2,26 \cdot 9)$ milk ejection and $1-2 \mathrm{~h}$ after oxytocin injection $(5 \cdot 1,28 \cdot 7,30 \cdot 8)$. Plasma progesterone concentrations were low in oxytocin-treated pigs and in lactating Pigs 23, 81 and 101 (mean \pm s.d. $365 \pm 155 \mathrm{pg} / \mathrm{ml}$ ). The mean concentration of progesterone in serial samples collected frequently from Pig $30(1789 \pm 623 \mathrm{pg} / \mathrm{ml})$ was significantly higher than in the other lactating pigs $(P<0.001)$.

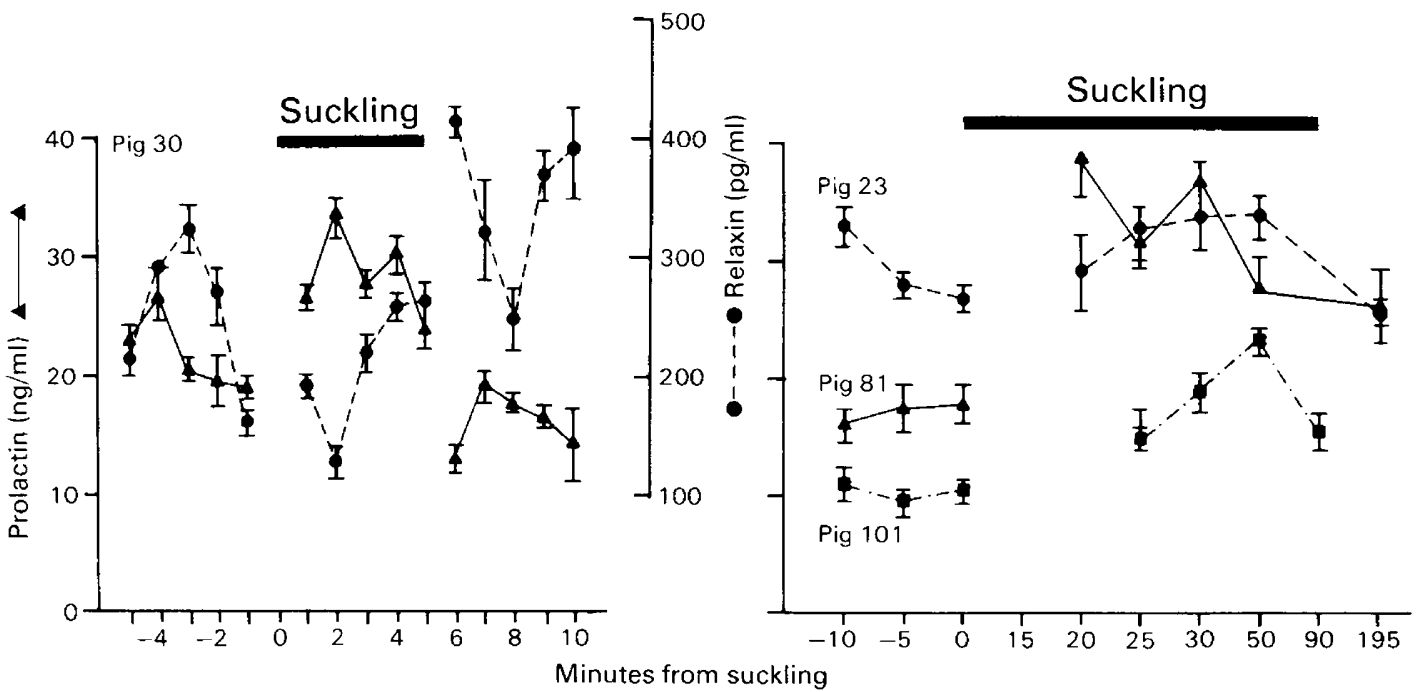

Text-fig. 3. Concentrations of relaxin and prolactin in maternal peripheral plasma in individual sows before, during and after suckling. Each point represents mean \pm s.d. of replicate determinations of one sample. Sampling time is non-linear over a time course of $3 \mathrm{~h} 25 \mathrm{~min}$. Relaxin values in Pigs 23, 81 and 101 were undetectable. 
Cyclic pigs

Haloperidol stimulated prolactin secretion in all 5 pigs. Prolactin concentrations increased from 6 to 32 times basal concentrations $(P=0.001)$. No significant changes occurred in plasma relaxin concentrations (Text-fig. 4). Plasma progesterone concentrations were high in all pigs (mean \pm s.d. $27 \cdot 4 \pm 10 \cdot 9 \mathrm{ng} / \mathrm{ml}, n=20)$.

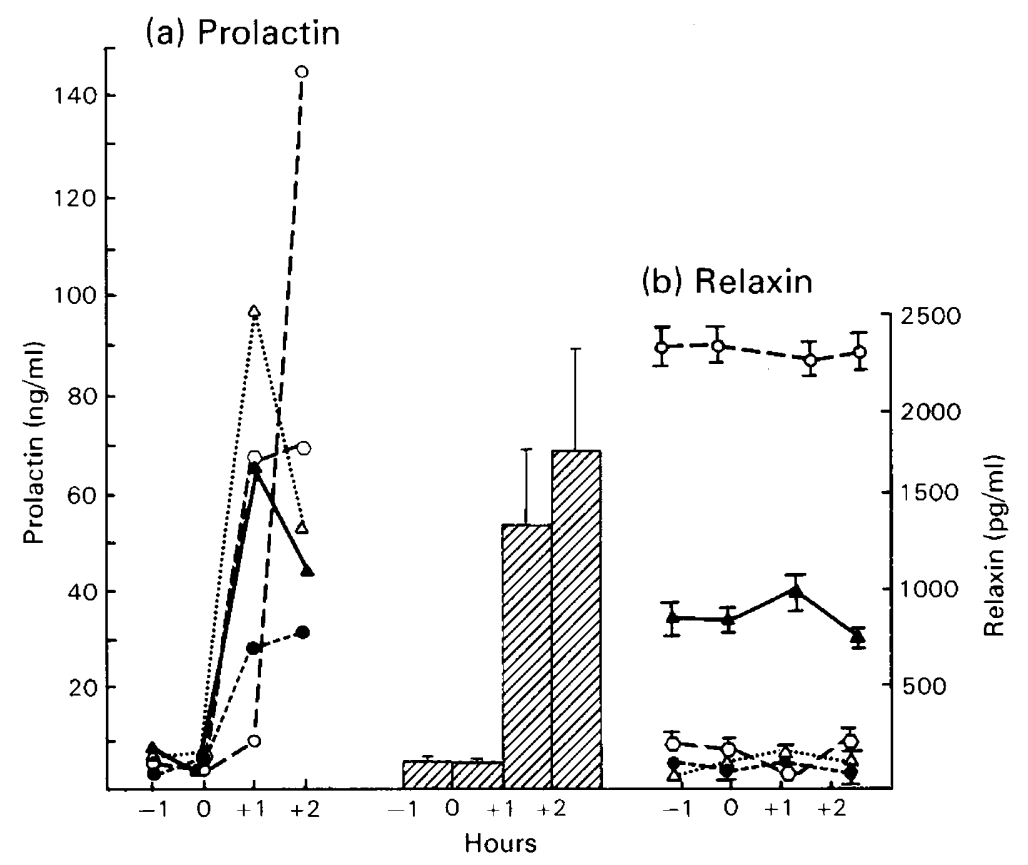

Text-fig. 4. Effect of an i.v. injection of $5 \mathrm{mg}$ haloperidol administered at $0 \mathrm{~h}$ on immunoreactive plasma prolactin and relaxin in cyclic pigs at Day 10-13 of the luteal phase. (a) Prolactin concentrations in individual animals; shaded bars represent mean \pm s.e.m. prolactin concentrations from the 5 pigs. (b) Relaxin concentrations in individual animals. Each point represents the mean \pm s.d. of replicate determinations of one sample.

\section{Discussion}

From our findings we conclude that stimulation of prolactin secretion during a period of the luteal phase of the cycle when ovarian relaxin content reaches peak concentrations (Sherwood \& Rutherford, 1981) or during lactation did not cause, over the same time course, an increase in plasma relaxin to concentrations detectable in our radioimmunoassay. However, an increase in mean relaxin concentration occurred in one suckling pig after the piglets had been removed, during the time when prolactin was declining to basal concentrations. More experiments are required to evaluate the significance of this observation. Our study does not adequately address the question of pulsatile release of prolactin and relaxin. The sampling times in our experiments were for the most part infrequent. It is possible that prolactin or relaxin was released periodically, for example, immediately after injection of oxytocin, a peptide with a short half-life (Chard, Boyd, Forsling, McNeilly \& Landon, 1970).

In our lactating pigs plasma concentrations of relaxin were very low, $<450 \mathrm{pg} / \mathrm{ml}$, and were undetectable in many samples. These observations agree with those of Sherwood et al. (1981) who, in similar experiments, found low or non-detectable levels of relaxin in lactating and suckling pigs. 
Anderson, Adair, Stromer \& McDonald (1982) also reported low plasma relaxin concentrations $(0.13 \mathrm{ng} / \mathrm{ml})$ in lactating pigs between Days 120 and 168 post coitum. However, we cannot conclude that low levels of relaxin in lactating pigs are of no physiological consequence. On the contrary, if relaxin's classical functions as a uterine relaxant or as a growth factor in mammary gland development (see review by Bryant-Greenwood, 1982) have physiological significance during pregnancy, then the very low concentrations relative to the pre-partum rise (Kendall et al., 1982) must be biologically active. Indeed, it is possible that subliminal changes in relaxin concentrations occur with suckling.

The relatively low plasma concentrations of relaxin in lactating pigs are in accord with evaluation of structure and function of the corpora lutea post partum. The corpus luteum is the only tissue known to synthesize relaxin in amounts detectable in the peripheral circulation of pigs (Steinetz, Beach \& Kroc, 1956; James, Niall, Kwok \& Bryant-Greenwood, 1977; Schwabe, McDonald \& Steinetz, 1977; Matsumoto \& Chamley, 1980). Cytoplasmic relaxin-containing granules (Kendall, Plopper \& Bryant-Greenwood, 1978; Anderson et al,, 1982) disappear after farrowing (Anderson et al., 1982). Not only do low levels of progesterone such as those found in lactating sows in our studies reflect low steroidogenic activity in the ovary, but rapid luteal regression is also detectable ultrastructurally after parturition (Anderson et al., 1982). It is therefore difficult to account for the observations of Afele, Bryant-Greenwood, Chamley \& Dax (1979) who found, in all 4 animals studied, that plasma relaxin values increased during suckling and nuzzling to concentrations of $6-16 \mathrm{ng} / \mathrm{ml}$. The sampling regimen used by Afele et al. (1979) may have been, in some instances, a little more frequent than the 1-min interval used in one pig in our study. Nonetheless, the rapid fall, in $0.5 \mathrm{~min}$, in relaxin concentrations after a peak (Afele et al., 1979) appears inconsistent with current knowledge of the half-life for relaxin (8-20 min), measured in non-pregnant pigs (Bryant-Greenwood, 1977; Sherwood \& Downing, 1983). However, the metabolic clearance rate of relaxin may differ in the lactating animal, and our observation that the pig with the highest relaxin levels also had the highest progesterone values suggests that a low level of luteal function can occur post partum, supporting the possibility that the CL of the pigs studied by Afele et al. (1979) were still active.

We thank Dr O. D. Sherwood for the gifts of porcine relaxin used for radioiodination; the NIAMDD Hormone Distribution Program for the porcine relaxin standard; $\mathrm{Dr}$ C. H. Li and Dr M. Grumbach for porcine prolactin and prolactin antiserum; Dr R. Carpenter and staff of the Veterinary Resources Division of the University of Texas Cancer Center, Science Park, Bastrop, Texas, and Mr A. E. Calvez and Mr. R. Heinemann of Bud Adams Pig Farm, Prairie View, Texas, for allowing us to sample their breeding herd; Ms S. Wilbourne for expert technical assistance; and Ms S. Barham for typing the manuscript. This project was partly supported by a UTHSC Biomedical Grant (J.Z.K.).

\section{References}

Afele, S., Bryant-Greenwood, G.D., Chamley, W.A. \& Dax, E.M. (1979) Plasma relaxin immunoactivity in the pig at parturition and during nuzzling and suckling. J. Reprod. Fert. 56, 451-457.

Anderson, L.L., Adair, V., Stromer, M.H. \& McDonald, W.G. (1982) Relaxin production and release after hysterectomy in the pig. Endocrinology 110, Suppl. p. 274, Abstr. 779.

Aubert, M.L., Grumbach, M.M. \& Kaplan, S.L. (1974) Heterologous radioimmunoassay for plasma human prolactin (hPRL); values in normal subjects, puberty, pregnancy and in pituitary disorders. Acta endocr., Copenh. 77, 400-464.
Bryant, G.D. \& Chamley, W.A. (1976) Changes in relaxin and prolactin immunoactivities in ovine plasma following suckling. $J$. Reprod. Fert. 46, 457-459.

Bryant-Greenwood, G.D. (1977) Radioimmunoassay of relaxin. In $A$ Handbook of Radioimmunoassay, pp. 243-273. Ed. G. Abraham. Marcel Dekker, Basle.

Bryant-Greenwood, G.D. (1982) Relaxin as a new hormone. Endocr. Rev. 3, 62-90.

Chard, T., Boyd, N.R.H., Forsling, M.L., McNeilly, A.S. \& Landon, J. (1970) The development of a radioimmunoassay for oxytocin. The extraction of oxytocin from plasma, and its measurement during parturition in human and goat blood. $J$. Endocr. 48, 223-234. 
Dusza, L. \& Krzymowska, H. (1979) Plasma prolactin concentrations during the oestrous cycle of sows. $J$. Reprod. Fert. 57, 511-514.

Dusza, L. \& Krzymowska, H. (1981) Plasma prolactin levels in sows during pregnancy, parturition and early lactation. J. Reprod. Fert. 61, 131-134.

Ekins, R.P. \& Newman, G. (1970) Theoretical aspects of saturation analysis. Acta endocr., Copenh., Suppl. 147, 11-36.

James, R., Niall, H.D., Kwok, S.C.M. \& BryantGreenwood, G.D. (1977) Primary structure of porcine relaxin: homology with insulin and related growth factors. Nature, Lond. 267, 544-546.

Kendall, J.Z. \& Richards, G.E. (1983) Regulation of relaxin and prolactin secretion in the pregnant pig: effects of litter size, fetal hypophysectomy and fetal death. In Factors Regulating Ovarian Function, pp. 421-426. Eds G.S. Greenwald \& P. Terranova. Raven Press, New York.

Kendall, J.Z., Plopper, G.C. \& Bryant-Greenwood, G.D. (1978) Ultrastructural immunoperoxidase demonstration of relaxin in corpora lutea from a pregnant sow. Biol. Reprod. 18, 94-98.

Kendall, J.A., Richards, G.E., Shih, Li-N. \& Farris, T.S. (1982) Plasma relaxin concentrations in the pig during the periparturient period: association with prolactin, estrogen and progesterone concentrations. Theriogenology 17, 677-687.
Matsumoto, D. \& Chamley, W.A. (1980) Identification of relaxins in porcine follicular fluid and in the ovary of the immature sow. J. Reprod. Fert. 58, 369-375.

Schwabe, C., McDonald, J.K. \& Steinetz, B.G. (1977) Primary structure of the $\beta$ chain of porcine relaxin. Biochem. Biophys. Res. Commun. 75, 503-510.

Sherwood, O.D. \& Downing, S.J. (1983) The chemistry and physiology of relaxin. In Factors Regulating Ovarian Function, pp. 381-410. Eds G.S. Greenwald \& P. Terranova, Raven Press, New York.

Sherwood, O.D. \& Rutherford, J.E. (1981) Relaxin immunoactivity levels in ovarian extracts obtained from rats during various reproductive states and from adult cycling pigs. Endocrinology 108, 1171-1177.

Sherwood, O.D., Nara, B.S., Welk, F.A., First, N.L. \& Rutherford, J.E. (1981) Relaxin levels in the maternal plasma of pigs, before, during and after parturition and before, during and after suckling. Biol. Reprod. 26, 65-71.

Steinetz, B.G., Beach, V.L. \& Kroc, R.L. (1956) The physiology of relaxin in laboratory animals. In Endocrinology of Reproduction, pp. 389-427. Ed. C.M. Lloyd. Academic Press, New York.

Taverne, M., Bevers, M., Bradshaw, J.M.C., Dieleman, S.J., Willemse, A.H. \& Porter, D.G. (1982) Plasma concentrations of prolactin, progesterone, relaxin and oestradiol-17 $\beta$ in sows treated with bromocriptine or indomethacin during late pregnancy. $J$. Reprod. Fert. 65, 85-96.

Received 21 February 1983 